Artikel Konseptual

Submitted: 18 Juni 2019

Accepted: 26 Juni 2019

Published: 30 Juni 2019

\title{
PARARATON SEBAGAI SUMBER SEJARAH: PEMANFAATANNYA DALAM PEM- BELAJARAN DI ERA DIGITAL
}

\begin{abstract}
Susanto Yunus Alfian
susantoyunusalfian@gmail.com

SMA Negeri 1 Sumberpucung, Kab. Malang

Abstract: One of the basic competencies of Indonesian History $10^{\text {th }}$ grade requires students to analyze the life of society, government, and culture during the Hindu and Buddhist kingdoms in Indonesia and to present the results of reasoning in written form. To facilitate the achievement of analytical skills and the ability to write history, the use of historical resources in Hindu Buddhist times such as Pararaton is a way that can be done.

This paper seeks to describe alternative solutions to use Pararaton as a historical source in learning so students can analyze and make written works demanding answers. The steps that can be taken in utilizing the Pararaton for historical learning include orientation, downloading, identification, exploration, and telling in written form.
\end{abstract}

Keywords: Pararatons, historical sources, digital, written works, Singasari, king

\section{PENDAHULUAN}

Dalam salah satu kompetensi dasar matapelajaran Sejarah Indonesia kelas X, siswa dituntut untuk menganalisis kehidupan masyarakat, pemerintahan, dan budaya pada masa kerajaan-kerajaan Hindu dan Buddha di Indonesia. Dalam hal ini, kerajaan Singasari menjadi bagian dari materi kerajaan-kerajaan Hindu dan Budha tersebut. Itu adalah tuntutan yang tercantum pada kompetensi dasar aspek pengetahuan. Sedangkan untuk materi pelajaran yang sama, aspek keterampilannya menuntut siswa untuk menyajikan hasil penalarannya dalam bentuk tulisan. Kompetensi menganalisis sebagai bagian dari Kompetensi Dasar 3.6 dan kemampuan membuat karya tulis sebagai Komptensi dasar 4.6. Kompetensi Dasar yang diawali dengan angka 3 merupakan ranah pengetahuan dan yang JPSI, Vol.2, No. 1, 2019 
diawali dengan angka 4 merupakan ranah keterampilan. Kompetensi dasar untuk dua ranah tersebut harus menjadi bagian utama dalam proses pembelajaran.

Untuk membuat pembelajaran Sejarah Indonesia yang memfasilitasi tercapainya kemampuan analisis dan kemampuan menulis sejarah, guru bisa memanfaatkan sumber sejarah. Siswa perlu diajak untuk mengkaji bukti sejarah (Seixas, 1996). Dengan mendalami sumber sejarah, kita bisa membawa kita untuk mengetahui masa lalu (von Heyking, 2004; Salinas \& Bellow, 2011). Suatu peristiwa bisa ditafsirkan berbeda oleh orang yang berbeda merupakan pertanyaan-pertanyaan utama pada unsur pemikiran historis epistemologi dan bukti (von Heyking, 2004). Siswa perlu diajak untuk memahami bagaimana seorang sejarawan dalam menggunakan bukti yang diperlukan dalam membuat narasi sejarah (von Heyking, 2004). Penggunaan sumber sejarah dalam pembelajaran merupakan salah satu kegiatan pemikiran historis (van Sledright, 2004). Pararaton sebagai sumber sejarah bisa dimanfaatkan untuk memfasilitasi pembelajaran yang menuntut siswa untuk menganalisis dan menyajikan tulisan tentang Kerajaan Singasari. Tulisan ini menyajikan bagaimana kita bisa memanfaatkan sumber sejarah Pararaton tersebut dalam pembelajaran Sejarah Indonesia di Kelas $\mathrm{X}$.

\section{INFORMASI PENTING DALAM PARARATON}

Serat Pararaton adalah sebuah kitab naskah Sastra Jawa Pertengahan yang digubah dalam bahasa Jawa Kawi. Judul lainnya adalah Serat Pararaton, Katuturanira Ken Angrok, Kitab Raja-Raja atau Cerita Tentang Ken Angrok. Kitab ini juga dikenal dengan nama Pustaka Raja, yang dalam Bahasa Sansekerta juga berarti kitab raja-raja.

Di akhir kisah Pararaton penulisnya hanya menulis nama desa dan catatan waktu ketika pengarangnya menyelesaikan tulisannya yakni 1535 Saka atau tepatnya 3 Agustus 1613. Bila dilihat dari tanggalnya Pararaton ditulis sejaman dengan berkuasanya Sultan Agung di Jawa. Meskipun tidak menyebutkan nama pengarang, kita bisa mengetahui beberapa informasi tentang waktu dan tempat penyusunannya (Munandar, 2011). Pararaton menyebutkan bahwa kitab ini disusun dalam bentuk sakakala pada tahun Kayambara-sagaraku yang para ahli menyamakan dengan angka tahun saka 1403 dan masehi tahun 1481. Pararaton menyebutkan bahwa kitab ini disusun di Sela Penek. Nama Sela Penek berarti batu yang terhimpit. Dengan kata lain bahwa tempat tersebut meru- 
pakan daerah batu cadas di pegunungan. Tempat pertapaan yang terdapat di pegunungan cadas ini sudah lama ada, seperti sisanya yang ada di Gunung Penanggungan pada masa Majapahit. Dengan kata lain bahwa tempat penyusunan kitab Pararaton tersebut berada di pertapaan yang terdapat di daerah pegunungan cadas.

Pararaton merupakan kronik berupa bunga rampai yang memitoskan Ken Arok. Pada zamannya, Pararaton dipandang sebagai sejarah atau kisah sejarah. Pararaton pada pengertian sekarang dapat digolongkan sebagai historiografi tradisional. Mitos tentang Ken Dedes yang bersinar, bercahaya membawa dampak sejarah besar khususnya berkaitan dengan berdirinya kerajaan Singasari (Dewi, 2013). Salah satu fungsi mitos adalah alat legitimasi.

Serat Pararaton dapat disandingkan dengan kitab Nagarakretagama dan prasastiprasasti kerajaan Singasari dan Majapahit. Historiografi tradisional masih mencampurkan antara fakta sejarah dengan mitos-mitos yang ada. Meskipun masing mengandung mitos, serat Pararton tetap bisa dipakai sebagai sumber sejarah. Para ahli bisa mengkoroborasikannya dengan Nagarakretagama dan prasasti-prasasti yang telah ditemukan. Namun demikian Pararaton ini menjadi rujukan para sejarawan juga dalam menganalisa sejarah Singasari dan Majapahit. Sangat berbeda dengan kitab Nagarakretagama yang ditulis oleh Mpu Prapanca pada masa Kerajaan Majapahit. Naskah ini cukup singkat, berupa 32 halaman seukuran folio yang terdiri dari 1126 baris. Isinya adalah sejarah raja-raja Singhasari dan Majapahit.

Serat Pararaton lebih cenderung ke arah sebuah karya sastra yang sarat dengan kisah kepahlawanan, intrik politik, asmara, dendam, dan hasrat akan harta dan kekuasaan. Serat Pararaton juga menggambarkan tentang perebutan kekuasaan, saling iri-dengki antar saudara, obsesi yang begitu tinggi, dendam pribadi. Di dalamnya penuh dengan mitos, fantasi, dan khayalan. Fakta dan fantasi menjadi saling berbaur. Antara fakta dan fiksi serta khayalan dan kenyataan saling berbaur. Tetapi ada beberapa hal yang sama dengan yang terdapat dalam prasati. Bila dibandingkan dengan Nagarakretagama, Serat Pararaton nampak lebih objektif karena tidak hanya membicarakan yang manismanis saja mengenai sejarah Singasari dan Majapahit.

Tujuan pengarang adalah untuk melegitimasi raja-raja Majapahit yang konon merupakan keturunan dari Ken Angrok dan Ken Dedes. Hal ini terbukti dari penjelasan "barang rahasia Ken Dedes yang bersinar" adalah pengakuan akan diri seorang ardhanareswari pada diri Ken Dedes. Ardhanareswari adalah seorang wanita yang memiliki tuah 
akan menurunkan raja-raja dan membawa keberuntungan. Terbukti dari pasangan Tunggul Ametung dan Ken Dedes yang menurunkan Anusapati dan Ranggawuni. Begitu juga dengan keturunan Ken Angrok dan Ken Dedes yang menurunkan Kertanegara, Raden Wijaya, Jayanagara, Tribhuwana Wijayatunggadewi, Hayam Wuruk, hingga Girindrawardhana sebagai raja terakhir Majapahit. Apabila Raden Patah juga merupakan anak dari Brawijaya yang juga merupakan keturunan Raden Wijaya, maka dapat dipastikan seluruh raja Demak, Pajang, hingga Mataram merupakan keturunan dari anak Dewa Brahma dan sang ardhanareswari.

Pararaton diawali dengan cerita mengenai inkarnasi Ken Arok, yaitu tokoh pendiri kerajaan Singhasari (1222-1292). Selanjutnya hampir setengah kitab membahas bagaimana Ken Arok meniti perjalanan hidupnya, sampai ia menjadi raja di tahun 1222. Penggambaran pada naskah bagian ini cenderung bersifat mitologis. Cerita kemudian dilanjutkan dengan bagian-bagian naratif pendek, yang diatur dalam urutan kronologis. Banyak kejadian yang tercatat di sini diberikan penanggalan. Mendekati bagian akhir, penjelasan mengenai sejarah menjadi semakin pendek dan bercampur dengan informasi mengenai silsilah berbagai anggota keluarga kerajaan Majapahit. Dari Ken Angrok lahir hingga menjelang jatuhnya Majapahit pada masa Bhre Pandan Salas (Sri Adi Suraprabhawa Singawikramawardhana Giripati Pasutabhupati Ketubhuta). Hanya saja uraian Pararaton mengenai keluarga raja-raja Majapahit sering terlampau singkat, kurang lengkap, dan kadang-kadang membingungkan, sehingga sejarawan harus jeli dalam menafsirkannya.

Pararaton dibagi menjadi dua bagian, yaitu tentang kisah Ken Arok hingga masa berakhirnya Majapahit. Bagian pertama mengisahkan Ken Arok dari lahir hingga meninggal, dan bagian kedua menyentuh sedikit kisah para raja Singasari hingga raja Majapahit.

Dalam kisah pembuka diceritakan bahwa Ken Angrok kecil yang rela menjadikan dirinya sebagai kurban persembahan kepada sebuah gapura besar sebagai pengganti seekor kambing berbulu merah yang tidak berhasil didapatkan oleh Empu Tapawengkeng. Tetapi ia meminta supaya kelak ia dapat pulang kembali kepada Dewa Wisnu dan dapat bereinkarnasi kembali. Kisah pun berganti dengan Dewa Brahma yang sedang berputar-putar mencari seorang wanita yang layak ditanami benih calon raja di bumi, dan sang dewa pun bertemu dengan seorang wanita yang baru saja menikah Ken Endok. Sang Dewa lalu menggauli Ken Endok dan menyuruh kepada Ken Endok supaya tidak bercerita kepada siapa pun perihal peristiwa ini dan melarang ia untuk bersenggama 
dengan suaminya. Dewa Brahma pun mengancam Ken Endok apabila ia tidak mampu menjaga rahasia ini maka suaminya akan mati. Ken Endok pun menceritakan peristiwa itu dan menceraikan suaminya, dan tak lama kemudian suaminya itu meninggal dan lahirlah seorang Ken Angrok dari rahim Ken Endok. Lalu oleh Ken Endok bayi itu dibuang ke kuburan dan akhirnya ditemukan dan diasuh oleh seorang pencuri yang bernama Lembong.

Dalam kisah pendahuluan dari Serat Pararaton, nuansa legitimasi akan Ken Angrok sudah sangat kental. Dia yang disebut sebagai anak dewa dan memiliki kekuatan gaib yang sangat kuat sudah dipaparkan dalam halaman-halaman awal Serat Pararaton. Dalam mitos Jawa, keturunan raja kelak pastilah juga menjadi raja. Dan Ken Angrok telah dilegitimasi sebagai keturunan Dewa Brahma, yang berarti juga hymelegitimasi para keturunan-keturunan Ken Angrok di masa sesudahnya memiliki darah sang dewa. Dengan begiti bisa dipastikan yang menjadi asal-usul legitimasi dalam Serat Pararaton ini bukan garis keturunan Dewa Brahma, melainkan garis keturunan Ken Angrok.

Kisah Pararaton lalu berlanjut pada pertemuan Ken Angrok dengan Dang Hyang Lohgawe, seorang Brahmana yang berasal dari Jambudwipa dan bertugas memastikan perintah Bhatara Wisnu dapat terlaksana. Dang Hyang Lohgawe mendapatkan tugas dari Bhatara Wisnu untuk membimbing Ken Angrok hingga menjadi raja di Jawadwipa kelak. Dang Hyang Lohgawe dan Ken Angrok pun akhirnya bekerja pada akuwu Tumapel yang bernama Tunggul Ametung. Hingga akhirnya Ken Angrok bertemu dengan Ken Dedes, istri dari sang akuwu Tumapel dan melihat bagian tubuh Ken Dedes yang menampakkan sinar.

Kisah ini pun berlanjut pada keinginan Ken Angrok untuk memiliki Ken Dedes. Dan intrik tentang kekuasaan pun dimulai dari sini, ketika niatan Ken Angrok bukan hanya menjadi suami bagi Ken Dedes, melainkan juga menjadi raja di Jawadwipa. Dengan meminta bantuan Empu Gandring untuk membuatkan sebuah keris sakti, Ken Angrok pun menggunakan "teori Machiavelisme" dalam memeroleh apa yang ia inginkan. Karena tidak sabaran, maka sang pembuat keris pun ia bunuh karena tidak menyelesaikan keris dalam waktu yang ia inginkan. Kutukan pun terlontar dari mulut Empu Gandring yang menyatakan tujuh orang raja akan meninggal dengan keris yang sama.

Ken Angrok lalu meminjamkan keris itu kepada sahabatnya, Kebo ljo. Sifat suka pamer Kebo ljo ia manfaatkan dalam rencana kudeta politisnya terhadap Tunggul Ametung. Ketika Kebo ljo sedang terlelap, ia pun mencurinya dan membunuh Tunggul Ametung malam itu juga. Dan tak lupa esok harinya ia memfitnah Kebo ljo dan membunuhnya 
dengan keris itu pula. Intrik politik yang tidak jelas siapa kawan dan siapa lawan ditunjukkan oleh Ken Angrok dalam Serat Pararaton. Begitu juga dengan kudeta politis yang berdarah pun ia perkenalkan kepada seluruh anak bangsa yang sedang belajar mengenai sejarah Singasari.

Ken Angrok lalu diangkat sebagai akuwu Tumapel yang menggantikan Tunggul Ametung. Dengan begitu maka Ken Dedes ikut menjadi istrinya pula. Ken Angrok pun meminta restu kepada para Brahmana untuk memakai nama Hyang Caturbuja alias Bhatara Guru untuk menyerang Daha. Pertempuran pun terjadi di sebelah utara Ganter dengan kemenangan di pihak Ken Angrok. Seusai peperangan di Desa Ganter, Ken Angrok mengubah status Tumapel yang semula merupakan negara bagian dari Kerajaan Daha (Kadiri) menjadi negara merdeka dengan nama Singasari. la pun mengangkat dirinya sebagai raja pertama Singasari yang bergelar Sri Rajasa Bhatara Sang Amurwabumi.

Anusapati menjadi raja menggantikan Ken Angrok. la memerintah dengan. Suatu hari Panji Tohjaya (anak dari Ken Angrok dengan selirnya, Ken Umang) mengajaknya mengikuti aduan ayam dan meminta izin untuk meminjam keris pusaka Empu Gandring milik ayahnya. Karena terlena oleh suasana aduan ayam, Anusapati menjadi tidak waspada lagi dan Panji Tohjaya segera memanfaatkan momen tersebut untuk menusuk jantung Anusapati.

Panji Tohjaya pun menjadi raja Singasari berikutnya. Namun kedua keponakannya Ranggawuni dan Mahisa Campaka justru mendapat dukungan kuat dari seluruh tentara Singasari sehingga terjadilah pemberontakan yang akhirnya membuat Panji Tohjaya terluka parah dan meninggal karena luka-luka.

Ranggawuni pun akhirnya naik tahta menjadi raja Singasari. la memimpin dengan gelar Sri Jayawisnuwardhana Sang Mapanji Seminingrat Sri Sakala Kalana Kulama Dhumardana Kamaleksana. Saat Ranggawuni menjadi raja, Mahisa Campaka menjadi raja hanggabaya dengan gelar Bhatara Narasinga. Ranggawuni adalah putra dari Anusapati yang berarti cucu dari Tunggul Ametung dan Ken Dedes. Sementara Mahisa Campaka adalah putra dari Mahisa Wongateleng yang berarti cucu dari Ken Angrok dan Ken Dedes.

Setelah Ranggawuni mangkat, ia digantikan oleh anaknya yang bernama Kertanegara. la memerintah dengan gelar Sri Maharaja Kertanegara. Pada masa kekuasaannya ia digambarkan sebagai pemimpin yang egois dan mementingkan perutnya. la adalah raja yang gemar pesta dan mabuk-mabukan. 
Dalam pemerintahan Kertanegara sempat terjadi perombakan pejabat pemerintahan. Empu Raganata diturunkan dari jabatan rakryan patih menjadi adhyaksa. Penggantinya bernama Kebo Tengah atau Panji Aragani. Arya Wiraraja dimutasi dari jabatan rakryan demung menjadi Bupati Sumenep. Panji Aragani digambarkan sebagai patih yang gemar pesta-pora, sehingga sang raja pun larut dalam pestanya. Pada saat prajurit istana tengah dalam Ekspedisi Pamalayu, jumlah tentara di istana sangatlah sedikit. Keadaan ini dimanfaatkan oleh Jayakatwang yang saat itu menjadi raja di Daha untuk menyerang Singasari. Kertanegara akhirnya tewas dalam pemberontakan Jayakatong dan dengan demikian berakhirlah sudah Kerajaan Singasari.

\section{STRATEGI PEMBELAJARAN}

Seperti diketahui bahwa Kompetensi Dasar (KD) empat adalah tentang keterampilan. Kitab Pararaton sebagai sumber sejarah bisa digunakan untuk mendalami materi pelajaran Sejarah Indonesia khususnya KD 3. 6 menganalisis perkembangan kehidupan masyarakat, pemerintahan, dan budaya pada masa kerajaan-kerajaan Hindu dan Buddha di Indonesia serta menunjukkan contoh bukti-bukti yang masih berlaku pada kehidupan masyarakat Indonesia masa kini. Kompetensi tersebut merupakan kompetensi dasar pada ranah pengetahuan. Sedangkan kompetensi dasar untuk aspek keterampilannya adalah KD 4.6. KD 4.6. Menyajikan hasil penalaran dalam bentuk tulisan tentang nilainilai dan unsur budaya yang berkembang pada masa kerajaan Hindu dan Buddha yang masih berkelanjutan dalam kehidupan bangsa Indonesia pada masa kini . Hal itu merupakan salah satu kompetensi dasar aspek keterampilan pada matapelajaran Sejarah Indonesia kelas X (Permendikbud Nomor 24 Tahun 2016). Kompetensi tersebut menuntut siswa untuk membuat sesuatu dalam bentuk tulisan.

Untuk bisa membuat karya tulis tersebut, strategi pembelajaran berbasis proyek bisa digunakan. Dalam keperluan ini, strategi pembelajarannya menggunakan lima tahapan yaitu tahap orientasi, download atau unduh, identifikasi, eksplorasi, dan penulisan cerita tokoh yang dituangkan dalam cerita tokoh. Pertama adalah tahap orientasi. Siswa diarahkan untuk mendalami kerajaan Singasari. Guru menyajikan tujuan pembelajaran. Dalam tujuan pembelajarannya, siswa harus membuat suatu cerita untuk tiap tokoh. Tujuan yang dimaksud berada pada aspek keterampilan dan bukan aspek pengetahuan. 
Aspek keterampilan tersebut berupa pembuatan cerita tentang kerajaan Singasari. Dalam hal ini, yang ditekankan adalah bahwa siswa harus membuat cerita tentang tokoh atau raja-raja kerajaan Singasari.

Kedua adalah tahap pengunduhan. Siswa mengunduh teks Pararaton. Teks pararaton ini bisa diakses bebas. Siswa bisa menggunakan laptop atau ponselnya untuk mengunduhnya. Teks pararaton ini ada yang berformat PDF dan Word. Untuk memastikan hasil unduhannya sebagai teks Pararaton yang asli, guru bisa mengajak siswa untuk meng-koroborasi dengan buku Pararaton yang telah terbit secara komersial di pasaran, salah satunya berjudul Pararaton: alih aksara dan terjemahannya oleh Kriswanto (2009). Buku tersebut bisa dibeli secara online dengan mudah. Jika guru sudah mempunyai buku itu, guru bisa meminta siswa untuk mengecek hasil unduhannya dengan yang dimiliki oleh guru.

Ketiga adalah tahap identifikasi. Siswa mengidentifikasi nama-nama tokoh dan candi tempat pendharmaan mereka. Nama-nama tokoh tersebut dikhususkan untuk nama-nama yang menjadi raja di kerajaan Singasari. Nama-nama yang sangat penting untuk didalami lebih lanjut adalah Ken Angrok, Anusapati, Wisnuwardhana, Kertanegara, Raden Wijaya. Siswa mempertebal (di-bold) nama-nama tersebut di laptop atau ponsel mereka. Tujuannya adalah untuk memfokuskan dan mempermudah mereka untuk mencarinya dengan lebih cepat tentang bagian-bagian di Pararaton yang berkaitan dengannya.

Keempat adalah tahap eksplorasi. Empat tokoh tersebut (Ken Angrok, Anusapati, Wisnuwardhana dan Kertanegara) kemudian dieksplorasi lagi lebih luas dan lebih dalam. Siswa diminta untuk melacak dan mencari lagi tentang nama resmi atau abhiseka, candicandi pendharmaan mereka, serta informasi-informasi lainnya yang berkaitan dengan empat tokoh tersebut. Nama-nama untuk tiap tokoh itu dicari juga di berbagai sumber sejarah. Siswa diarahkan untuk mencari sumber-sumber arkeologis atau pun sumber sastra. Sumber arkeologis bisa berupa prasasti-prasasti, baik prasasti peninggalan Kerajaan Singasari atau pun Kerajaan Majapahit. Sumber prasati di antaranya adalah prasasti Camundi, Prasati Wurare, Prasasti Gajahmada. Sumber sastra diantaranya adalah Negarakertagama.

Terakhir adalah tahap menceritakan dalam bentuk tulisan. Siswa diminta untuk menceritakan secara tertulis masing-masing tokoh dalam dua lembar kertas. Struktur tu- 
lisan terdiri dari empat bagian yaitu pendahuluan, isi, kesimpulan, dan daftar rujukan. Bagian pendahuluan disajikan dalam dua paragraf saja. Paragraf pertama berisi alasan penulis atau siswa terhadap judul yang dipilihnya dan paragraf kedua menyampaikan apa sub-sub topic yang akan ditulisnya di bagian isi. Bagian isi merupakan bagian inti yang mungkin mengisi dari satu setengah halaman dari dua halaman yang diwajibkan. Yang dituliskan di bagian isi ini adalah sub-sub topik dari tokoh yang dibahas tersebut. Meskipun membahas tokoh yang sama, sub-sub topik ini bisa berbeda antar kelompok. Perbedaan itu tergantung dari sudut padang atau perspektif atau fokus yang berbeda antar kelompok.

Setelah siswa menyelesaikan penulisan cerita raja-raja kerajaan Singasari, hasilnya yang terdiri dari dua lembar tersebut dikirimkan kepada guru. Pengirimannya bisa dilakukan lewat grup Whatsapp atau pun email guru. Guru bisa membuat kesepakatan dengan siswa untuk memilih cara pengiriman yang lebih mudah sampai ke guru.

\section{KELEBIHAN PEMANFAATAN SUMBER SEJARAH DALAM PEMBELAJARAN}

Dengan menggunakan Pararaton dalam pembelajaran Sejarah Indonesia, ada tiga keuntungan. Pertama, siswa bisa menggunakan kemampuan berpikir historis. Dengan menggunakan sumber sejarah Pararaton dalam pembelajaran, siswa akan mencari informasi tentang penulisnya siapa, kapan ditulis, isinya tentang apa. Pertanyaan-pertanyaan itu merupakan proses pemikiran historis. Selanjutnya dengan makin mendalami tokoh atau raja Singasari yang tercantum dalam Pararaton dengan mencari informasi dari sumber lain, siswa juga melakukan koroborasi. Mereka akan makin menggunakan pemikiran tingkat tinggi. Mereka akan menganalisis, mengecek, mengkritisi berbagai hal yang saling bertentangan dan kontradiktif. Hal ini memancing siswa untuk makin berpikir dan bernalar. Jadi mereka akan terasah kemampuan berpikir historis dan kemampuan menalarnya.

Kedua, siswa bisa membuat karya tulis sejarah. Untuk bisa menulis, siswa harus memiliki informasi. Informasi yang cukup akan menjadi bahan yang cukup untuk membuat suatu karya tulis. Pararaton sebagai sumber informasi menjadi salah satu bahan yang penting dalam menyusun karya tulis. Apalagi siswa diminta untuk mendalami dengan mencari dan mengumpulkan sumber lain. Tentu informasi yang mereka peroleh akan menjadi lebih banyak. Semakin banyak bahan akan semakin menunjang dalam 
menghasilkan karya tulis. Pemanfaatan Serat Pararaton dalam pembelajaran sangat bagus dalam meningkatkan kemampuan menulis sejarah.

Dan ketiga, siswa menjadi terlibat aktif dalam pembelajaran sejarah. Dengan pembelajaran yang memanfaatkan Pararaton dalam KD 3.6 dan KD 4.6, siswa sangat diuntungkan. Mereka tidak hanya mencari satu sumber sejarah, tapi juga akan mencari sumber-sumber selain Pararaton. Mereka mengidentifikasi, menganalisis, membandingkan antar hal, mencocokkan, mengkoroborasi, mengevaluasi. Mereka melakukan pemikiran dari tingkat rendah hingga tingkat tinggi.

\section{KESIMPULAN}

Untuk membuat pembelajaran Sejarah Indonesia yang memfasilitasi tercapainya kemampuan analisis dan kemampuan menulis sejarah, guru bisa memanfaatkan sumber sejarah. Siswa diajak untuk mengkaji bukti sejarah. Penggunaan sumber sejarah dalam pembelajaran merupakan salah satu kegiatan pemikiran historis. Sumber sejarah bisa digunakan untuk melakukan pemikiran tingkat tinggi. Kompetensi menganalisis sebagai Kompetensi Dasar 3.6 dan kemampuan membuat karya tulis sebagai Komptensi dasar 4.6. Kompetensi Dasar yang diawali dengan angka 3 merupakan ranah pengetahuan dan yang diawali dengan angka 4 merupakan ranah keterampilan. Kompetensi dasar untuk dua ranah tersebut harus menjadi bagian utama dalam proses pembelajaran.

Strategi pembelajaran-berbasis proyek ini menggunakan empat tahapan. Pertama adalah tahap orientasi. Kedua adalah tahap pengunduhan. Ketiga adalah tahap identifikasi. Keempat adalah tahap eksplorasi. Dan terakhir adalah tahap menceritakan dalam bentuk tulisan.

Ada tiga kelebihan dari pembelajaran dengan menggunakan sumber sejarah, khususnya Pararaton. Pertama, siswa bisa menggunakan kemampuan berpikir historis. Kedua, siswa bisa membuat karya tulis sejarah. Ketiga, siswa menjadi terlibat aktif dalam pembelajaran sejarah.

\section{DAFTAR RUJUKAN}

Dewi, T. K. S. (2013). Arok Dedes Dan Pararaton: transformasi dan dinamika sastra dalam wacana globalisasi sastra. Atavisme, 16 (1), 119-128. 
Kriswanto, A. (2009). Pararaton: alih aksara dan terjemahannya. Jakarta: Penerbit Wedatama Widya Sastra.

Munandar, A. A. (2011). Menafsirkan ulang riwayat Ken Arok dan Kendedes dalam kitab Pararaton. Jurnal Manasa, 1 (1), 1-15.

Salinas, C. \& Bellows, M. K. (2011). Preservice Social Studies teachers' historical thinking and digitized primary sources: what they use and why. Contemporary Issues in Technology and Teacher Education, 11 (2), 184-204.

Seixas, P. (1996). Conceptualizing the growth of historical understanding. Dalam David R. Olson \& Nancy Torrance (Eds).The handbook of education and human development. 765783. Oxford: Blackwell Publishers.

Van Sledright, B. A. (2004). What does it mean to think historically ...and how do you teach it? Social Education, 68 (3), 230-241.

Von Heyking, A. ( 2004 ). Historical thinking in the Elementary Years: a review of current research. Canadian Social Studies, 39 (1), 1-17. 